3 Effects of land use and weather on the presence and abundance of mosquito-

\title{
Ontario, Canada
}

7 Miarisoa Rindra Rakotoarinia ${ }^{1}$, F. Guillaume Blanchet ${ }^{2,3,4}$, Dominique Gravel $^{2}$, David Lapen ${ }^{5}$,

8 Patrick A. Leighton ${ }^{1}$, Nicholas H. Ogden ${ }^{1,6}$, Antoinette Ludwig 1,6

$10{ }^{1}$ Groupe de recherche en épidémiologie des zoonoses et santé publique (GREZOSP), Faculté de

11 médecine vétérinaire, Université de Montréal, Montréal, Canada

$12 \quad{ }^{2}$ Département de biologie, Université de Sherbrooke, Sherbrooke, Canada

$13{ }^{3}$ Département de mathématique, Université de Sherbrooke, Sherbrooke, Canada

$14{ }^{4}$ Département des sciences de la santé communautaire, Université de Sherbrooke, Sherbrooke, 15 Canada

$16{ }^{5}$ Eastern Cereal and Oilseed Research Center, Agriculture and Agrifood Canada, Ottawa, 17 Canada

$18{ }^{6}$ Public Health Sciences Division, National Microbiology Laboratory, Public Health Agency of 19 Canada, St-Hyacinthe, Canada

20

$21 *$ Corresponding author

22 E-mail : mr.rakotoarinia.randriamialy@umontreal.ca 


\section{Abstract}

24 Weather and land use can significantly impact mosquito abundance and presence, and by

25 consequence, mosquito-borne disease (MBD) dynamics. Knowledge of vector ecology and mosquito species response to these drivers will help us better predict risk from MBD. In this study, we evaluated and compared the independent and combined effects of weather and land use on mosquito species occurrence and abundance in Eastern Ontario, Canada. Data on occurrence and abundance $(245,591$ individuals) of 30 mosquito species were obtained from mosquito capture at 85 field sites in 2017 and 2018. Environmental variables were extracted from weather and land use datasets in a 1-km buffer around trapping sites. The relative importance of weather and land use on mosquito abundance (for common species) or occurrence (for all species) was evaluated using multivariate hierarchical statistical models. Models incorporating both weather and land use performed better than models that include weather only for approximately half of species (59\% for occurrence model and 50\% for abundance model). Mosquito occurrence was mainly associated with temperature whereas abundance was associated with precipitation and

37 temperature combined. Land use was more often associated with abundance than occurrence. For most species, occurrence and abundance were positively associated with forest cover but for some there was a negative association. Occurrence and abundance of some species (47\% for occurrence model and $88 \%$ for abundance model) were positively associated with wetlands, but negatively associated with urban (Culiseta melanura and Anopheles walkeri) and agriculture (An.

42 quadrimaculatus, Cs. minnesotae and An. walkeri) environments. This study provides predictive 43 relationships between weather, land use and mosquito occurrence and abundance for a wide 44 range of species including those that are currently uncommon, yet known as arboviruses vectors. 
45 Elucidation of these relationships has the potential to contribute to better prediction of MBD risk,

46 and thus more efficiently targeted prevention and control measures.

47 Keywords: land use, weather, mosquito-borne disease, mosquito vectors, occurrence, abundance,

$48 \quad$ Ontario

\section{Introduction} mosquito species identified as occurring in Canada in an exhaustive list compiled in the 1980s [2]. Recently, six new endemic species have been added to the list: Ochlerotatus ventrovittis; Oc. japonicus; Culex salinarius; Cx. erraticus; Anopheles perplexens, and An. crucians [3, 4].

59 Furthermore, new exotic invasive species from the United States have been repeatedly detected 60 in southern Ontario. Aedes aegypti were detected in 2016 and 2017 in southern Ontario. These

61 are though to be repeated introductions, with no evidence of over-winter survival, however the 62 more cold-tolerant Ae. albopictus is now thought to have become established [5]. 
Three mosquito species are mainly responsible for the transmission of WNV in eastern Canada:

67 Aedes vexans and the two species of the Culex pipiens and CX. restuans, which are often enumerated together due to difficulty in distinguishing them [6]. Culiseta melanura is the main vector for EEEV [7, 8]. CSV have several potential vectors including Ochlerotatus and Culiseta spp. [9-21]. Other mosquito species present in Canada may also be involved in the transmission of arboviruses as suggested by laboratory studies [22-24]. Therefore, monitoring communities of mosquito species, rather than single species, may be more effective for understanding the ecology of arboviruses and predicting risk from them.

Many studies have highlighted the importance of weather and climate as determinants of the spatio-temporal distribution and abundance of mosquitoes [25-28]. Climate change [29], may be driving current expansions in the geographical range of mosquitoes, particularly northern expansion of ranges [30-32]. Weather and climate impact the occurrence and abundance of mosquitos in multiple ways [33]. Increasing temperature can lead to faster inter-stadial development and shorter life cycles. However, the association between weather and mosquito occurrence as well as abundance is not straightforward. High temperatures above $35^{\circ} \mathrm{C}$ kills most mosquitoes species $[34,35]$ but higher average temperatures could also increase the winter survival rate of eggs and promote earlier hatching, and prolong the season of mosquito activity [36]. Increased rainfall may increase reproduction and abundance by increasing suitable larval habitats. Conversely, excessive rainfall can also decrease abundance via egg destruction and leaching of larvae [37].

Weather and climate are not the sole factors influencing species distributions, abundance and diversity. Land use change related to agriculture and urban expansion, and increased forest loss is the largest driver of landscape modification worldwide [38, 39]. Several studies have 
89 linked land cover and land use change to mosquito community changes [40-49]. Urban greening,

90 as a result of urban conservation initiatives, will likely enhance resources for arthropods

91 including mosquitoes [50, 51]. Increased crop irrigation in agricultural environments and

92 associated drainage networks may increase larval habitat for several mosquito species. Habitat

93 structure determines mosquito breeding and resting sites, and nutrition of the different mosquito

94 developmental stages [49, 50, 52-54]. Thus, attempting to understand how land use activities, as

95 well as climate and weather, influence composition and abundance of mosquitos is essential to

96 understand the ecology of mosquito species. impact on public health. Individual differences in species traits were included in this study as they can influence the species response to the explanatory variables. As a first cut analysis, we used readily available remote sensing and meteorological data. Much finer analyzes may follow 


\section{Materials and methods}

\section{Study region}

The study sites are located in the greater Ottawa area and the adjacent South Nation river

114 catchment (SN) in eastern Ontario, Canada (Fig 1). The city of Ottawa covers $2,778.13 \mathrm{~km}^{2}$ with

$115 \sim 1$ million inhabitants, while the SN river basin covers an area of $\sim 3900 \mathrm{~km}^{2}$ with an estimated

116 population of approximately 115,000 . The SN study area is predominately agricultural land, with

117 patchy forested areas and some suburban locations [73]. The climate is semi-continental with a

118 warm, humid summer and a very cold winter [74].

Fig 1. Study region and sampling site locations (Public Health Ontario in Ottawa (29 sites)

and the South Nation River watershed (56 sub-sites)).

\section{Mosquito variables, sampling design and mosquito identification}

Mosquito data came from two sources. Prospective field study was undertaken at 56 SN

field sites in 2017 and 2018. Data were also obtained from the ongoing West Nile virus

127 were captured at 29 sites. At the SN sites, a stratified sampling design was used. Traps were set

128 in locations with (1) suburban and, (2) agricultural land uses class, that each contained seven

129 sites. Each site regrouped four sub-sites according to the presence of water and woodlot features:

130 (1) an area with no water and no wooded area, (2) an area with water but no woods, (3) an area 
131 with water that is partially wooded and (4) an area with water that is densely wooded. The

132 number of traps employed by a public health unit in Ontario at a given location varied

133 significantly from year to year. To ensure comparability between the two datasets, we kept only

134 the traps that were in operation during a minimum of 15 weeks. For both datasets, mosquitoes

135 were collected on each site one night every other week from May to end of September (end of

136 August for 2017 in the $\mathrm{SN}$ sites), using $\mathrm{CO}_{2}$ baited Centers for Disease Control and Prevention

137 (CDC) miniature light-traps. Trapped mosquitoes were identified and counted by species. $C x$.

138 pipiens and $C x$. restuans were lumped into a single group $C x$. pipiens-restuans due to their

139 morphological similarity

\section{Weather variables}

Temperature (minimum and maximum) and precipitation during the study period were

143 extracted from a gridded weather data : Daymet (Daily Surface Weather And Climatological

144 Summaries) (https://daymet.ornl.gov/) [75]. These data are available at a daily time step across a

$1451 \mathrm{~km} \times 1 \mathrm{~km}$ spatial resolution. Weather data were associated with mosquito trapping locations by

146 averaging weather conditions in a one-kilometer radius around each trapping site. Given that

147 larval development to adult stage can occur between 5 to 90 days $[76,77]$, these daily variables

148 were averaged over different time period: 5, 30 and 90 days before the capture. With the weather

149 during the day of capture, a total of 12 weather variables were used as explanatory in the models

150 (S3 Table). 


\section{Land use variables}

A buffer zone with a radius of $1 \mathrm{~km}$ was created around each trapping site, to approximate the average flight range of the 27 studied species $[78,79]$. The percent coverage of

154 land use classes was extracted from annual crop inventory data for 2017 and 2018 [78], within

155 each buffer. Crop inventory data were reclassified into seven land use variables (S4 Table).

\section{Mosquito traits}

In this study, we also studied how traits influenced the species response to the resistance of the egg to desiccation and 5) typical larval habitat (S6 Table).

\section{Statistical methods}


172 coordinates of the sampling locations and allows to account for the proximity of certain sampling

173 locations. The db-MEMs that significantly characterize spatial autocorrelation were included as

174 covariates in the model. Construction and test of db-MEM were performed using the adespatial

175 R package [81].

177 were explored using a Hierarchical Modeling of species Community (HMSC) analysis [80].

178 Mosquito abundance data were explored using over-dispersed Poisson models, whereas for

179 mosquito presence/absence data probit models were used. HMSC model parameters are

180 estimated using a Gibbs sampler. For the probit model, the MCMC chain was run for 300,000

181 and 320,000 iterations, for weather-only and weather-and-land-use models respectively, half of

182 which were burn-in iterations. For the over-dispersed Poisson model, weather-only and weather-

183 and-land-use models were run for 200,000 and 220,000 iterations respectively, half of which

184 were burn-in iterations. Convergence was assessed using the Geweke's convergence diagnostics

185 [82]. Convergence was assumed to be reached for a parameter if it had a Geweke diagnostic

186 value lower than two. Trace and density plots for all parameters were also checked visually to

187 ensure convergence was reached.

Adjusted Efron's pseudo- $\mathrm{R}^{2}$ was computed to compare the occurrence and abundance

189 models. This metric is a relative measure of model fit, obtained by calculating the proportion of 190 explained variance over the total variance in the data [83] adjusted for the number of parameters

191 in the model. We also assessed the predictive performance of occurrence-based models by using

192 the area under the receiver operating characteristic curve (AUC) and the root-mean-squared error

193 (RMSE). AUC evaluates the ability of the model to discriminate accurately occurrence and

194 absence. We used the RMSE and the correlation between predicted and observed abundance for 
195 the abundance models. All multivariate models were carried out with the "HMSC" package [84]

196 through the R statistical language version 4.0.2 [85].

Models with and without land use were compared by looking at the values of their

198 respective adjusted pseudo- $\mathrm{R}^{2}$. The explained variation was partitioned into components related

199 to fixed effects (weather, land use, spatial component) and random effects (two weeks' period

200 and sample identification) for each species, following the procedure proposed by Ovaskainen et

201 al. (2017) [80].

202

203

204

\section{Results}

205

\section{Mosquito sampling}

Thirty species belonging to seven genera (Aedes (Ae), Anopheles (An), Coquillettidia

207

(Cq), Culiseta (Cs), Culex (Cx), Ochlerotatus (Oc), Psorophora (Ps)) were detected with a total of 245,591 adult female mosquitos captured. The biweekly average abundance of each species

Fig 2. Seasonal changes in biweekly averaged abundance for all species over 2017 and 2018 
cantator, Oc. communis, Oc. dorsalis, Oc. excrucians, Oc. fitchii, Oc. intrudens, Oc. japonicus, Oc. provocans, Oc. punctor, Oc. sticticus, Oc. triseriatus, Ps. ciliata and Ps. ferox.

\section{Added value of land use as a predictor of mosquito occurrence and}

\section{abundance}

Of the thirty species observed, only 27 were included in statistical analysis due to lack of information on the traits of three species (An. barberi, Oc. sticticus and Cx. salinarius). All models for all species converged. Density plots are provided in the supporting information (S1720 Fig). The community-level explained variation, illustrated by the mean-values of the speciesspecific adjusted Efron's pseudo- $\mathrm{R}^{2}$, was computed for each model ranging from 0.21 to 0.28 (Table 1). The values of the community-level adjusted Efron's pseudo- $\mathrm{R}^{2}$ suggest that including land-use in the model in addition to weather can modestly improve overall predictive power. However, because the community-level explained variation is the average $\mathrm{R}^{2}$ across all species, it hides the significant variation in independent species (from 0.053 to 0.988 for the occurrence model and from 0.040 to 0.725 for the abundance) (Fig 3). For some species, the adjusted Efron's pseudo- $\mathrm{R}^{2}$ was negative, indicating that these models are less likely than sampling a random variable from a probability distribution, so results from these species are not interpreted.

Table 1. Community-level explained variance of the four models

\begin{tabular}{|c|c|c|}
\hline & $\begin{array}{c}\text { Community-level adjusted } \\
\text { pseudo- } \mathbf{R}^{2} \text { of weather-only } \\
\text { model }\end{array}$ & $\begin{array}{c}\text { Community-level adjusted } \\
\text { pseudo- } \mathbf{R}^{2} \text { of weather-and- } \\
\text { land-use model }\end{array}$ \\
\hline Occurrence (27 species) & 0.26 & 0.28 \\
\hline Abundance (12 species) & 0.21 & 0.22 \\
\hline
\end{tabular}


When variation was partitioned according to each species, there was an increase of the adjusted Efron's pseudo- $\mathrm{R}^{2}$ values in $59 \%$ of species from the occurrence model and $50 \%$ of species from the abundance model (Fig 3 and 4). This suggests that adding the land use component does not necessarily improve the quality of the models and this is true for both occurrence and abundance. The community-level adjusted pseudo- $\mathrm{R}^{2}$ corresponding to land use was low ( 0.013 and 0.015 for occurrence and abundance, respectively) compared to that of the weather variable ( 0.069 and 0.057 for occurrence and abundance respectively). In all cases, weather information was most crucial for predicting mosquito occurrence and abundance data in the region.

Fig 3. Variation partitioning according to species among weather, land use, spatial fixed that of weather-and-land-use model (0.28). Each bar corresponds to one species.

Fig 4. Variation partitioning according to species among weather, land use, spatial fixed that of weather-and-land-use model (0.22). Each bar corresponds to one species.

253 in explaining the response variables. For example, approximately half of the whole variation 254 explained was attributed to the sample random effect (10\%) suggesting that the sample have 255 relatively strong effects on patterns of species occurrence and abundance while the spatial fixed 
256 effect variance ranged between 3.66 and 8.37\%. However, the community-level adjusted Efron's

257 pseudo-R ${ }^{2}$ corresponding to the temporal unit (“Biweek”) remained very small for all species

$258(<1 \%)$. The comparison between the occurrence-based model and the abundance-based model

259 revealed that modeling occurrence explains more variation in the data (Community-level

260 adjusted Efron's pseudo- $\mathrm{R}^{2}=0.28$ ) than the models for abundance (Community-level adjusted

261 Efron's pseudo- $\mathrm{R}^{2}=0.22$ ) except for two species (Oc. trivittatus and An. walkeri). Finally, the

262 proportion of variance related to each group of covariates and random variables was relatively

263 similar for the same species whether in the occurrence model or in the abundance model.

\section{Weather predictors of mosquito occurrence and abundance}

As our primary goal was to evaluate the added value of including land use when

modeling mosquito occurrence and abundance, we only present the results obtained from

weather-and-land-use models. However, results of the weather-only models are presented in the

273 one to three months prior to mosquito capture being those most important. 
277 (average of the marginal distribution of the model parameter above zero) or a negative

278 (average of the marginal distribution of the model parameter below zero) association

279 between the variables and mosquito occurrence or abundance. Orange cells show

280 relationships between weather variables and the response variables (occurrence /

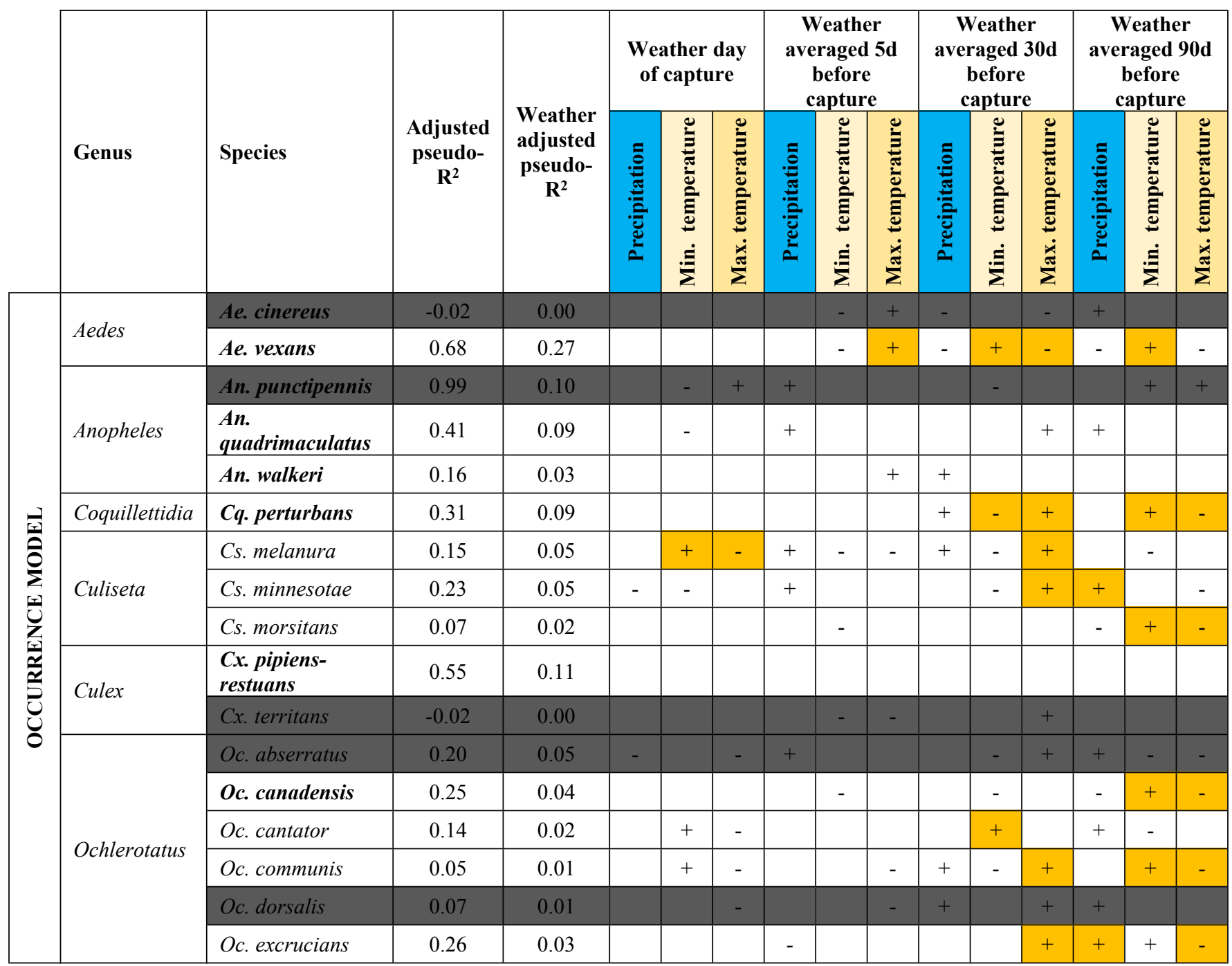




\begin{tabular}{|c|c|c|c|c|c|c|c|c|c|c|c|c|c|c|c|}
\hline & Oc. fitchii & 0.09 & 0.02 & - & + & & & - & - & + & & & - & + & - \\
\hline & Oc. intrudens & 0.12 & 0.02 & & + & - & & & - & & - & + & & + & - \\
\hline & Oc. japonicus & 0.61 & 0.04 & - & + & - & & & & - & + & - & + & & + \\
\hline & Oc. provocans & 0.35 & 0.21 & & & & + & - & - & - & - & + & & + & - \\
\hline & Oc. triseriatus & 0.42 & 0.05 & & & & & & + & - & + & - & & & \\
\hline & Oc. trivittatus & 0.41 & 0.15 & + & & & & & + & & & - & - & + & - \\
\hline & Oc. stimulans & 0.25 & 0.03 & & & & & & 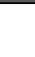 & & - & + & & + & - \\
\hline & Oc. punctor & 0.63 & 0.35 & & - & + & + & & - & & & + & & - & - \\
\hline$D_{\mathrm{cor}}$ & Ps. ciliata & -0.02 & 0.00 & - & + & & & & & & + & & + & & \\
\hline rsoropnora & Ps. ferox & 0.19 & 0.04 & & + & - & + & - & - & - & & & & & \\
\hline
\end{tabular}

\begin{tabular}{|c|c|c|c|c|c|c|c|c|c|c|c|c|c|c|c|c|}
\hline \multirow{12}{*}{ 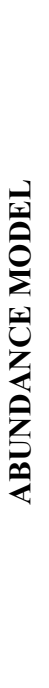 } & \multirow{2}{*}{ Aedes } & Ae. cinereus & 0.07 & 0.02 & - & & & & - & + & - & - & & + & & + \\
\hline & & Ae. vexans & -0.06 & -0.02 & & & & - & - & + & - & & - & + & - & + \\
\hline & \multirow{3}{*}{ Anopheles } & An. punctipennis & 0.21 & 0.01 & & & & & - & & & & & & + & \\
\hline & & $\begin{array}{l}\text { An. } \\
\text { quadrimaculatus }\end{array}$ & 0.04 & 0.03 & & & & + & - & + & - & & + & + & & + \\
\hline & & An. walkeri & 0.19 & 0.07 & & & & & - & + & + & & + & + & - & + \\
\hline & Coquillettidia & Cq. perturbans & 0.72 & 0.30 & & - & & & & + & & - & + & & - & \\
\hline & Culex & $\begin{array}{l}\text { Cx. pipiens- } \\
\text { restuans }\end{array}$ & 0.11 & 0.02 & & - & + & & - & + & & - & + & + & + & \\
\hline & \multirow{5}{*}{ Ochlerotatus } & Oc. canadensis & 0.51 & 0.07 & & & & & - & + & - & - & - & & + & \\
\hline & & Oc. provocans & 0.33 & 0.06 & & & & + & - & & - & & + & + & - & - \\
\hline & & Oc. trivittatus & 0.18 & 0.03 & & & & - & & + & - & + & - & + & + & \\
\hline & & Oc. japonicus & 0.15 & 0.04 & & + & - & & & & & & & & + & \\
\hline & & Oc. stimulans & 0.24 & 0.06 & & + & & & & & & - & + & + & + & - \\
\hline
\end{tabular}

Precipitation - Occurrence and abundance displayed generally positive responses to

287 precipitation. Precipitation had a greater effect when it was averaged over a large number of days

288 prior to sampling relative to a smaller number of days, especially for the abundance models.

289 Total precipitation during the day of capture did not have a major effect. The occurrence of only

290 Oc. provocans, and the abundance of only An. quadrimaculatus were positively associated with

291 precipitation averaged over 5 days before capture $\left(\operatorname{Prcp}_{5}\right)$. Precipitation averaged over 30 days

292 had a positive relationship with An. walkeri and a negative relationship with Oc. canadensis.

293 Precipitation averaged over 90 days was positively associated with the abundance of $A n$.

294 quadrimaculatus, An. walkeri, Cx. pipiens-restuans and Oc. stimulans, and the occurence of Cs. 
295

296

297

298

299

300

301

302

303

304

305

306

minnesotae and Oc. excrucians. The occurrence of Oc, fitchii was negatively associated with the precipitation averaged over 90 days.

Minimum temperature - The effect of the minimum temperature differed according to the time lag before capture. The minimum temperature averaged over 90 days before capture $\left(\operatorname{Tmin}_{90}\right)$ was a significant determinant for occurrence in $42 \%$ of species. The minimum temperature averaged over 30 days $\left(\mathrm{Tmin}_{30}\right)$ was positively associated with the occurrence of $A e$. vexans and Oc. cantator and negatively associated with the occurrence of Cq. perturbans and Oc. stimulans. In the abundance model, the effect of $\operatorname{Tmin}_{30}$ was negative for $38 \%$ of species. The minimum temperature averaged over 5 days $\left(\operatorname{Tmin}_{5}\right)$ was a determinant of abundance for only two species (An. quadrimaculatus and Oc. canadensis) but with a negative effect. Finally, the minimum temperature of the day of capture was positively associated with the occurrence of Cs. melanura and Oc. japonicus.

Maximum temperature - The maximum temperature was significantly associated with mosquito occurrence and abundance. In the occurrence model, the maximum temperature averaged over 30 days $\left(\operatorname{Tmax}_{30}\right)$ was positively associated with nine of 19 species, but negatively associated with $A e$. Vexans. In addition, $\operatorname{Tmax}_{30}$ was positively associated with the abundance of Cq. perturbans and Oc. stimulans and negatively associated with the abundance of $O c$.

trivittatus. In the abundance model, the maximum temperature averaged over 5 days $\left(\operatorname{Tmax}_{5}\right)$ stood out as the variable most frequently associated with mosquito abundance with a positive association with five of eight species. The maximum temperature of the day of capture was negatively associated with the occurrence of Cs. melanura. 


\section{Land use predictors of mosquito occurrence and abundance}

Land use variables had generally weaker associations with mosquito occurrence and

319 abundance than weather variables as shown by the low adjusted Efron's pseudo- $\mathrm{R}^{2}$ values for the

320 land use component. We nevertheless decided to retain the results of the species for which an

321 improvement in the model fit was observed.

Overall, the land use effects were consistent between occurrence and abundance models.

The major land use drivers common to all mosquito species were wetland, forest and bare ground

(Table 3). There was a positive relationship between wetland coverage and mosquito occurrence species for the abundance model). 
abundance of three species (38\%) but was positively associated with abundance of $A n$.

quadrimaculatus.

Table 3. Comparison of the significant and relatively strong effects of land use on mosquito

\begin{tabular}{|c|c|c|c|c|c|c|c|c|c|c|c|}
\hline & \multirow[b]{2}{*}{ Genus } & \multirow[b]{2}{*}{ Species } & \multirow[b]{2}{*}{$\begin{array}{c}\text { Adjusted } \\
\text { pseudo- } \\
\mathbf{R}^{2}\end{array}$} & \multirow[b]{2}{*}{$\begin{array}{c}\text { Land use } \\
\text { adjusted } \\
\text { pseudo- } \\
\mathbf{R}^{2}\end{array}$} & \multicolumn{7}{|c|}{ Land use } \\
\hline & & & & & 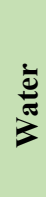 & 思 & 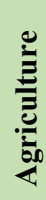 & 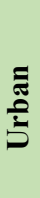 & 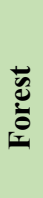 & 总 & 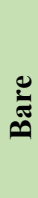 \\
\hline \multirow{18}{*}{ 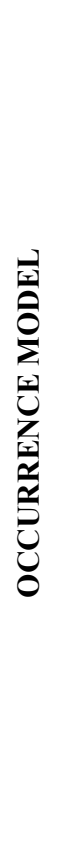 } & \multirow{2}{*}{ Aedes } & Ae. cinereus & -0.02 & -0.0017 & & + & - & & + & + & - \\
\hline & & Ae. vexans & 0.68 & 0.0143 & - & + & + & & & + & - \\
\hline & \multirow{3}{*}{ Anopheles } & An. punctipennis & 0.99 & 0.0118 & + & + & - & & - & 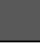 & + \\
\hline & & An. quadrimaculatus & 0.41 & 0.0521 & + & & - & - & - & + & + \\
\hline & & An. walkeri & 0.16 & 0.0383 & + & + & - & - & - & + & - \\
\hline & Coquillettidia & Cq. perturbans & 0.31 & 0.0175 & & + & - & & + & - & - \\
\hline & \multirow{3}{*}{ Culiseta } & Cs. melanura & 0.15 & 0.0131 & + & + & - & - & 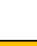 & - & - \\
\hline & & Cs. minnesotae & 0.23 & 0.0153 & - & - & - & - & + & - & \\
\hline & & Cs. morsitans & 0.07 & 0.0076 & - & + & & & + & - & - \\
\hline & \multirow{2}{*}{ Culex } & Cx. pipiens-restuans & 0.55 & 0.0464 & & + & - & + & - & & + \\
\hline & & Cx. territans & -0.02 & -0.0008 & & & - & - & - & & + \\
\hline & \multirow{7}{*}{ Ochlerotatus } & Oc. abserratus & 0.20 & 0.0097 & - & & - & - & + & - & - \\
\hline & & Oc. canadensis & 0.25 & 0.0379 & - & + & & + & + & - & - \\
\hline & & Oc. cantator & 0.14 & 0.0053 & & + & - & - & & & - \\
\hline & & Oc. communis & 0.05 & 0.0015 & - & + & & - & + & - & - \\
\hline & & Oc. dorsalis & 0.07 & 0.0017 & & + & - & - & & & - \\
\hline & & Oc. excrucians & 0.26 & 0.0059 & & - & & & + & - & - \\
\hline & & Oc. fitchii & 0.09 & 0.0051 & - & + & - & - & + & - & - \\
\hline
\end{tabular}




\begin{tabular}{|c|c|c|c|c|c|c|c|c|c|c|}
\hline & Oc. intrudens & 0.12 & 0.0027 & - & & & & + & - & - \\
\hline & Oc. japonicus & 0.61 & 0.0145 & - & + & & - & - & & - \\
\hline & Oc.provocans & 0.35 & 0.0108 & - & - & + & & + & - & - \\
\hline & Oc. triseriatus & 0.42 & 0.0073 & - & + & 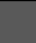 & . & 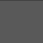 & - & - \\
\hline & Oc. trivittatus & 0.41 & 0.0151 & - & + & + & - & + & + & - \\
\hline & Oc. stimulans & 0.25 & 0.0042 & . & + & + & + & + & - & - \\
\hline & Oc. punctor & 0.63 & 0.0113 & - & - & - & & + & - & \\
\hline \multirow{2}{*}{ Psorophora } & Ps. ciliata & -0.02 & -0.0007 & - & + & - & - & + & - & - \\
\hline & Ps. ferox & 0.19 & 0.0074 & - & + & - & - & + & - & - \\
\hline
\end{tabular}

\begin{tabular}{|c|c|c|c|c|c|c|c|c|c|c|c|}
\hline \multirow{12}{*}{ 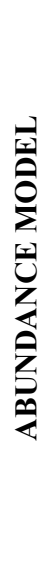 } & \multirow{2}{*}{ Aedes } & Ae. cinereus & 0.07 & 0.0074 & - & + & - & & + & & - \\
\hline & & Ae. vexans & -0.06 & -0.0013 & - & + & & - & - & & - \\
\hline & \multirow{3}{*}{ Anopheles } & An. punctipennis & 0.21 & 0.0107 & & + & - & - & - & & + \\
\hline & & An. quadrimaculatus & 0.04 & 0.0010 & + & & - & - & - & + & + \\
\hline & & An. walkeri & 0.19 & 0.0045 & + & + & - & - & - & + & - \\
\hline & Coquillettidia & Cq. perturbans & 0.72 & 0.0113 & - & + & - & - & + & - & \\
\hline & Culex & Cx. pipiens-restuans & 0.11 & 0.0222 & & + & & & - & + & + \\
\hline & \multirow{5}{*}{ Ochlerotatus } & Oc. canadensis & 0.51 & 0.0108 & - & + & - & + & + & - & - \\
\hline & & Oc. provocans & 0.33 & 0.0463 & - & + & + & . & + & - & - \\
\hline & & Oc. trivittatus & 0.18 & 0.0462 & - & + & + & + & + & - & - \\
\hline & & Oc. japonicus & 0.15 & 0.0083 & - & + & - & - & 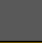 & - & - \\
\hline & & Oc. stimulans & 0.24 & 0.0105 & & + & + & + & + & - & - \\
\hline
\end{tabular}

354 Canada, while highlighting the importance of land use in determining the occurrence and

355 abundance of certain species. By jointly analyzing data from multiple species using the HMSC

356 approach, we were able to gain unique insight into ecological drivers of species that are less

357 abundant and therefore infrequently studied, yet are known vectors for several important mosquito-borne diseases. 


\section{The importance of cumulative weather effects}

Our results clearly demonstrate the importance of the accumulation over several days, or weeks to months of favorable climatic conditions for the development of mosquitoes. Mosquitoes are ectothermic organisms, each developmental stage may be sensitive to weather conditions, and there is a species-specific range of temperature conditions that permit completion of their life cycle and, if we are in the optimum of the range, is the shortest possible [86]. However, for univoltine species, i.e. having only one generation per year, high temperature for one month may speed up the life cycle which leads to an earlier emergence of the adults. As adult lifespan can last few weeks at most [77], the cohorts that appeared after one month are no longer present after 90 days. Indeed, we observed that, together with the positive effect of a higher temperature averaged over 30 days before capture, we often saw a negative association

371 when a longer period is considered, i.e. 90 days.

Weather variables that affect mosquito occurrence are not necessarily the same that affect abundance. The importance of precipitation, especially accumulated over several weeks before

374 mosquito capture, appears only in our abundance models. This cumulative effect of precipitation

375 has to be considered alongside the time period between egg laying and adult emergence. The 376 multiplication of mosquitoes depends closely on the availability of breeding sites favored by 377 rainfall as well as the presence of water in these same sites, whether natural or artificial. If the 378 water evaporates quickly, this will give less time for larvae to develop and limit the number of 379 emerging adults [87]. abundance, compared to the cumulative effects of temperatures over several days. However, for 
382

383

384

385

386

387

388

389

390

391

392

393

394

395

low. In part, a relatively low effect of land use categories could be due to the spatial resolution of

403

some species, optimal temperatures for adult daily activity apparently remained relatively important, and not in the expected direction. Two species, Oc. japonicus and Cs. melanura, were positively associated with a warm minimal temperature on the day of the capture. The scarce information from the existing literature indicates that Cs. melanura is nocturnal [88] and therefore, adults may be more active during the night when it is generally cooler $\left(\operatorname{Tmin}_{0}\right)$ than during the day $\left(\operatorname{Tmax}_{0}\right)$, and making warm nights potentially favorable to Cs. melanura. Explanations for Ae.japonicus are less obvious. This species is known to be cold tolerant [89], and may be more active during cool days (intermediate temperatures).

An apparent limitation of our study was to use the weather as a proxy of mosquito seasonality. However, mosquitoes don't respond instantaneously to weather but accumulate past effects of this latter to develop cohorts over the season. Using the average weather over previous time interval partly solves this issue but our approach doesn't represent a seasonal model per se.

Our model will still predict high abundance of mosquitos in early or late summer where weather conditions are exceptionally favorable, no matter if the population had enough time to develop.

Thus, our study highlights the need of a seasonal model for community, currently non-existent, that will be constructed on population dynamics to reflect this cumulative build up of the population over the season.

\section{Land use influence on mosquito} land use data being $30 \mathrm{~m}$, which may be too coarse to adequately represent variation in mosquito 
habitat; a finer land use data resolution $(\sim 1 \mathrm{~m})$ could lead to high adjusted pseudo- $\mathrm{R}^{2}$ values [46].

405 The sample random effect and / or the spatial fixed effects included in the models often showed a relatively high proportion of variance, which could be further evidence that the full impact of

407 land use on mosquito occurrence was not captured in this study. Indeed, our spatial descriptors

408 (db-MEM) likely captured relevant land use structure that were not accounted for in our study 409 such as biogeographic barriers [81].

Wetland appeared to be an important driver of mosquito occurrence or abundance for many species. This is not surprising since wetlands and water constitute a fundamental habitat

412 for the mosquito life cycle, in particular for An. quadrimaculatus, An. walkeri, Cq. pertubans, of several mosquito species. Wooded areas generally serve as refuge for adult mosquitoes,

417 especially for the CSV vectors Oc. excrucians, Oc. communis and Oc. stimulans. These results

418 are consistent with the limited information in the literature which describes, for example, that

419 Oc. excrucians can be found in a wide range of habitats according to Wood et al. [90] while

420 Darsie et al [91] mention that these species larvae tend to prefer wooded spring pools and semi-

421 permanent wetlands with abundant vegetation. The 'forest' class was negatively associated with

422 Cx. pipiens-restuans (presence) and Anopheles (abundance), which is consistent with several

423 studies $[58,63,92]$. Cx. pipiens-restuans are also known to be urban species although a positive

424 association with 'urban' was not detected in our study. Indeed, urban landscapes are very

425 heterogeneous and could themselves be classified into several categories according to the

426 presence of woodlands and aquatic environments. A more detailed characterization of the urban 
427 micro-habitat may help better define the relationships between this land use class (urban) and

428 mosquitoes. The negative association between 'forest' and the abundance of An. walkeri could

429 be explained by the fact that the adults of this species generally stay near their larval aquatic

430 habitats, in contrast to other species of Anopheles (An. quadrimaculatus and An. punctipennis)

431 which leave their breeding sites during the day to seek shelters [91].

434 prevent completion of the mosquito life cycle.

437 minnesotae is naturally adapted to specific marshy environments including sedge and cattail

438 marshes which may be found at the edge of some agricultural fields [91, 93]. However, cattails

439 are considered as invasive plants and are subject to considerable efforts to eliminate them by

440 most farmers, reducing habitat for this species. Anopheles species generally prefer pristine

441 freshwater environments such as peat bogs and unpolluted freshwater swamps [90, 91], while

442 wetlands in agricultural land are often contaminated with chemical agents (fertilizers, pesticides,

443 etc.) $[94,95]$, which may explain the negative association between these species and the

444 agriculture land use class.

446 perturbans, Oc. canadensis, Oc. communis, Oc. intrudens and Oc. stimulans) may be explained

447 by the lack of wetland in this type of habitat, dominated by shrubs, including grasses, herbs, and 448 geophytes. 
In summary, we found evidence that mosquito occurrence and abundance are related to

450 land use variables. We detected some common patterns among mosquito species with regard to

451 their response to natural land use variables (water and forest) but more specific response to other

452 land use variables such as agricultural land and shrubland.

\section{Conclusion}

457 focused on mosquito abundance. However, it is important to determine how multiple species are

458 influenced by these variables since models based on a single or small number of species do not

459 provide a portrait of the whole community including rare disease vectors. This study provides

460 baseline multi-species associations where species respond differently to a given set of

461 environmental conditions. Our study also demonstrates the relevance of including land use in

462 predicting mosquito occurrence and abundance. If temperature and precipitation are primary

463 drivers in mosquito development, appropriate habitat is also required for many species. Our

464 findings suggest that the impact of land use and weather together on mosquito occurrence and

465 abundance is species-specific and may have diverging impacts on whether a species can survive

466 (occurrence) or thrive (abundance). Future research should develop our understanding of

467 mosquito community preferences in terms of habitat and climatic conditions. Several analytical

468 approaches are now available to work at the multi-species level and study the ecological

469 connections between species. One of the main outcome of such study would be to confirm if

470 human-altered environments favor the multiplication of a few species of mosquitoes that are 
471 flexible habitat generalists, to while excluding a diversity of more specialized mosquitoes which

472 are becoming increasingly rare. We expect that this imbalance in terms of biodiversity would

473 favor species that are efficient vectors of human disease. Further information about mosquito

474 community ecology could allow vector management strategies to be more targeted with respect

475 to anthropogenic pressures including deforestation, urbanization and agriculture.

476

477

478 Acknowledgement

We are grateful to all AAFC field teams, Curtis Russel and folks from Public Health

480 Ontario for providing Ontario surveillance data, Julie Légaré for mosquito identification and

481 Christopher Fernandez Prada for lab facilities. We thank the Groupe de Recherche sur

482 l'Épidémiologie des Zoonoses et Santé Publique (GREZOSP) and the Public Health Agency of

483 Canada (PHAC) which funded the study and supported its execution.

\section{Author Contributions}

485 Conceptualization: Miarisoa Rindra Rakotoarinia, Antoinette Ludwig, Patrick Leighton,

486 Nicholas H. Ogden, David Lapen, Guillaume Blanchet, Dominique Gravel.

487 Formal Analysis: Miarisoa Rindra Rakotoarinia, Guillaume Blanchet, Antoinette Ludwig.

488 Funding Acquisition: Antoinette Ludwig, David Lapen. 
489 Methodology: Miarisoa Rindra Rakotoarinia, Antoinette Ludwig, Patrick Leighton, Nicholas H.

490 Ogden, David Lapen, Guillaume Blanchet, Dominique Gravel.

491 Resources: Antoinette Ludwig, Patrick Leighton, Nicholas H. Ogden, David Lapen, Guillaume

492 Blanchet, Dominique Gravel.

493 Software: Guillaume Blanchet, Dominique Gravel.

494 Supervision: Antoinette Ludwig, Patrick Leighton, Nicholas H. Ogden, David Lapen,

495 Guillaume Blanchet, Dominique Gravel.

496 Visualization: Miarisoa Rindra Rakotoarinia, Guillaume Blanchet, Antoinette Ludwig.

497 Writing - Original Draft Preparation: Miarisoa Rindra Rakotoarinia, Antoinette Ludwig.

498 Writing - Review \& Editing: Miarisoa Rindra Rakotoarinia, Antoinette Ludwig, Patrick

499 Leighton, Nicholas H. Ogden, David Lapen, Guillaume Blanchet, Dominique Gravel.

\section{References}

503 1. Organisation Mondiale de la Santé O. Maladies Tropicales Négligées. 2020 [updated

504 20202020-09-29]. Available from:

505 https://www.who.int/neglected_diseases/vector_ecology/mosquito-borne-diseases/fr/.

506 2. Wood D, Dang P, Ellis R. The insects and arachnids of Canada. Part 6. The mosquitoes

507 of Canada. Diptera: Culicidae: Canadian Government Publishing Centre.; 1979. 
508 3. Darsie RF, Jr. Revision of Darsie and Ward (1981) to include Ochlerotatus japonicus

509 Theobald and a checklist of species referred to the genus Ochlerotatus in the Nearctic Region. J

510 Am Mosq Control Assoc. 2002;18(4):237-40. PubMed PMID: 12542180.

511 4. Giordano BV, Gasparotto A, Hunter FF. A Checklist of the 67 Mosquito Species of

512 Ontario, Canada. Journal of the American Mosquito Control Association. 2015;31(1):101-3. doi:

513 10.2987/14-6456R.1.

514 5. Giordano B, Gasparotto A, Liang P, Nelder M, Russell C, Hunter F. Discovery of an

515 Aedes (Stegomyia) albopictus population and first records of Aedes (Stegomyia) aegypti in

516 Canada. Medical and veterinary entomology. 2020;34(1):10-6.

517 6. Kramer LD, Styer LM, Ebel GD. A global perspective on the epidemiology of West Nile 518 virus. Annu Rev Entomol. 2008;53:61-81.

519 7. Armstrong PM, Andreadis TG. Eastern equine encephalitis virus in mosquitoes and their 520 role as bridge vectors. Emerging infectious diseases. 2010;16(12):1869.

521 8. Molaei G, Andreadis TG, Armstrong PM, Anderson JF, Vossbrinck CR. Host feeding

522 patterns of Culex mosquitoes and West Nile virus transmission, northeastern United States.

523 Emerging infectious diseases. 2006;12(3):468.

524 9. Andreadis TG, Anderson JF, Armstrong PM, Main AJ. Isolations of Jamestown Canyon 525 virus (Bunyaviridae: Orthobunyavirus) from field-collected mosquitoes (Diptera: Culicidae) in 526 Connecticut, USA: a ten-year analysis, 1997-2006. Vector Borne Zoonotic Dis. 2008;8(2):175527 88. doi: 10.1089/vbz.2007.0169. PubMed PMID: 18386967.

528 10. LeDuc JW. Review Article: The Ecology Of California Group Viruses. Journal of 529 Medical Entomology. 1979;16(1):1. 
530 11. Andreadis TG, Capotosto PM, Shope RE, Tirrell SJ. Mosquito and arbovirus surveillance

531 in Connecticut, 1991-1992. J Am Mosq Control Assoc. 1994;10(4):556-64. PubMed PMID:

5327707064.

533 12. Goff G, Whitney H, Drebot MA. Roles of Host Species, Geographic Separation, and

534 Isolation in the Seroprevalence of Jamestown Canyon and Snowshoe Hare Viruses in

535 Newfoundland. Applied and Environmental Microbiology. 2012;78(18):6734-40. doi:

536 10.1128/AEM.01351-12. PubMed PMID: PMC3426688.

537 13. Harris MC, Yang F, Jackson DM, Dotseth EJ, Paulson SL, Hawley DM. La Crosse Virus

538 Field Detection and Vector Competence of Culex Mosquitoes. Am J Trop Med Hyg.

539 2015;93(3):461-7. Epub 2015/07/16. doi: 10.4269/ajtmh.14-0128. PubMed PMID: 26175029;

540 PubMed Central PMCID: PMCPMC4559680.

541 14. Defoliart GR, Watts DM, Grimstad PR. Changing patterns in mosquito-borne

542 arboviruses. J Am Mosq Control Assoc. 1986;2(4):437-55. Epub 1986/12/01. PubMed PMID:

5432906983.

544 15. DeFoliart GR, Anslow RO, Hanson RP, Morris CD, Papadopoulos O, Sather GE.

545 Isolation of Jamestown Canyon serotype of California encephalitis virus from naturally infected

546 Aedes mosquitoes and tabanids. Am J Trop Med Hyg. 1969;18(3):440-7. PubMed PMID:

$547 \quad 5768778$.

548 16. Parkin WE, Hammon WM, Sather GE. Review of current epidemiological literature on

549 viruses of the California arbovirus group. Am J Trop Med Hyg. 1972;21(6):964-78. Epub

550 1972/11/01. PubMed PMID: 4564448. 
551 17. Heard PB, Zhang MB, Grimstad PR. Isolation of Jamestown Canyon virus (California

552 serogroup) from Aedes mosquitoes in an enzootic focus in Michigan. J Am Mosq Control Assoc.

553 1990;6(3):461-8. PubMed PMID: 2230774.

554 18. Mokry J, Artsob H, Butler R. Studies on California serogroup virus activity in

555 Newfoundland, Canada, 1980-83. Mosq News. 1984;44:310-4.

556 19. Boromisa RD, Grimstad PR. Virus-vector-host relationships of Aedes stimulans and

557 Jamestown Canyon virus in a northern Indiana enzootic focus. Am J Trop Med Hyg.

558 1986;35(6):1285-95. PubMed PMID: 2878626.

559 20. Iversen J, Hanson RP, Papadopoulos O, Morris CV, DeFoliart GR. Isolation of viruses of

560 the California encephalitis virus group from boreal Aedes mosquitoes. Am J Trop Med Hyg.

561 1969;18(5):735-42. PubMed PMID: 5810801.

562 21. Boromisa RD, Grayson MA. Oral transmission of Jamestown Canyon virus by Aedes

563 provocans mosquitoes from northeastern New York. J Am Mosq Control Assoc. 1991;7(1):42-7.

564 Epub 1991/03/01. PubMed PMID: 1675258.

565 22. Kramer LD, Reisen WK, Chiles RE. Vector competence of Aedes dorsalis (Diptera:

566 Culicidae) from Morro Bay, California, for western equine encephalomyelitis virus. J Med

567 Entomol. 1998;35(6):1020-4. PubMed PMID: 9835696.

568 23. Turell MJ, O'Guinn ML, Dohm DJ, Jones JW. Vector competence of North American

569 mosquitoes (Diptera: Culicidae) for West Nile virus. J Med Entomol. 2001a;38(2):130-4. doi:

570 10.1603/0022-2585-38.2.130. PubMed PMID: 11296813.

571 24. Vaidyanathan R, Edman JD, Cooper LA, Scott TW. Vector competence of mosquitoes

572 (Diptera:Culicidae) from Massachusetts for a sympatric isolate of eastern equine

573 encephalomyelitis virus. J Med Entomol. 1997;34(3):346-52. PubMed PMID: 9151501. 
574 25. Hongoh V, Berrang-Ford L, Scott M, Lindsay L. Expanding geographical distribution of

575 the mosquito, Culex pipiens, in Canada under climate change. Applied geography. 2012;33:53-

57662.

577 26. Ogden NH, Milka R, Caminade C, Gachon P. Recent and projected future climatic

578 suitability of North America for the Asian tiger mosquito Aedes albopictus. Parasites \& vectors.

$579 \quad 2014 ; 7(1): 532$.

580 27. Ogden N, Gachon P. Changements climatiques et maladies infectieuses: À quoi pouvons-

581 nous nous attendre. Relevé des maladies transmissibles au Canada. 2019;45(4):83-8.

582 28. Ogden NH, St-Onge L, Barker IK, Brazeau S, Bigras-Poulin M, Charron DF, et al. Risk

583 maps for range expansion of the Lyme disease vector, Ixodes scapularis, in Canada now and with

584 climate change. International Journal of Health Geographics. 2008;7(1):1-15.

585 29. Solon S, Qin M, Manning Z. Contribution of working group I to the fourth assessment

586 report of the intergovernmental panel on climate change, 2007. Cambridge University Press,

587 Cambridge; 2007.

588 30. Hertig E. Distribution of Anopheles vectors and potential malaria transmission stability in

589 Europe and the Mediterranean area under future climate change. Parasites \& vectors.

$590 \quad 2019 ; 12(1): 18$.

591 31. Kraemer MU, Reiner RC, Brady OJ, Messina JP, Gilbert M, Pigott DM, et al. Past and 592 future spread of the arbovirus vectors Aedes aegypti and Aedes albopictus. Nature microbiology. $593 \quad 2019 ; 4(5): 854-63$.

594 32. Armstrong PM, Andreadis TG, Shepard JJ, Thomas MC. Northern range expansion of the 595 Asian tiger mosquito (Aedes albopictus): Analysis of mosquito data from Connecticut, USA.

596 PLoS neglected tropical diseases. 2017;11(5):e0005623. 
597 33. Ogden NH, Lindsay LR. Effects of climate and climate change on vectors and vector-

598 borne diseases: ticks are different. Trends in parasitology. 2016;32(8):646-56.

599 34. Buxton PA. The effect of climatic conditions upon populations of insects. Transactions of 600 the Royal Society of Tropical Medicine and Hygiene. 1933;26(4):325-56.

601 35. Heinrich B. Insect thermoregulation. 1981.

602 36. Eisen L, Monaghan AJ, Lozano-Fuentes S, Steinhoff DF, Hayden MH, Bieringer PE. The 603 impact of temperature on the bionomics of Aedes (Stegomyia) aegypti, with special reference to

604 the cool geographic range margins. Journal of medical entomology. 2014;51(3):496-516.

605 37. Clements AN. The biology of mosquitoes: development, nutrition and reproduction:

606 Chapman \& Hall London; 1992.

607 38. Curtis PG, Slay CM, Harris NL, Tyukavina A, Hansen MC. Classifying drivers of global 608 forest loss. Science. 2018;361(6407):1108-11.

609 39. DeFries RS, Rudel T, Uriarte M, Hansen M. Deforestation driven by urban population 610 growth and agricultural trade in the twenty-first century. Nature Geoscience. 2010;3(3):178-81.

611 40. Rosà R, Marini G, Bolzoni L, Neteler M, Metz M, Delucchi L, et al. Early warning of 612 West Nile virus mosquito vector: climate and land use models successfully explain phenology 613 and abundance of Culex pipiens mosquitoes in north-western Italy. Parasites \& vectors.

$614 \quad 2014 ; 7(1): 269$.

615 41. Zahouli JB, Koudou BG, Müller P, Malone D, Tano Y, Utzinger J. Effect of land-use 616 changes on the abundance, distribution, and host-seeking behavior of Aedes arbovirus vectors in 617 oil palm-dominated landscapes, southeastern Côte d'Ivoire. PloS one. 2017;12(12):e0189082. 
618 42. Marí RB, Jiménez-Peydró R. Differences in mosquito (Diptera: Culicidae) biodiversity

619 across varying climates and land-use categories in Eastern Spain. Entomologica Fennica.

$620 \quad 2011 ; 22(3): 190-8-8$.

621 43. de Valdez MRW. Mosquito species distribution across urban, suburban, and semi-rural

622 residences in San Antonio, Texas. Journal of Vector Ecology. 2017;42(1):184-8.

623 44. Steiger DBM, Ritchie SA, Laurance SG. Mosquito communities and disease risk

624 influenced by land use change and seasonality in the Australian tropics. Parasites \& vectors.

$6252016 ; 9(1): 387$.

626 45. Asigau S, Parker PG. The influence of ecological factors on mosquito abundance and

627 occurrence in Galápagos. Journal of Vector Ecology. 2018;43(1):125-37.

628 46. Landau KI, van Leeuwen WJ. Fine scale spatial urban land cover factors associated with 629 adult mosquito abundance and risk in Tucson, Arizona. Journal of Vector Ecology.

$630 \quad 2012 ; 37(2): 407-18$.

631 47. Steiger DBM, Ritchie SA, Laurance SG. Land use influences mosquito communities and

632 disease risk on remote tropical islands: a case study using a novel sampling technique. The

633 American journal of tropical medicine and hygiene. 2016;94(2):314-21.

634 48. Chaves LF, Hamer GL, Walker ED, Brown WM, Ruiz MO, Kitron UD. Climatic

635 variability and landscape heterogeneity impact urban mosquito diversity and vector abundance 636 and infection. Ecosphere. 2011;2(6):1-21.

637 49. Roiz D, Ruiz S, Soriguer R, Figuerola J. Landscape effects on the presence, abundance 638 and diversity of mosquitoes in Mediterranean wetlands. PLoS One. 2015;10(6):e0128112. 
639 50. Yang L, Turo KJ, Riley CB, Inocente EA, Tian J, Hoekstra NC, et al. Can urban greening

640 increase vector abundance in cities? The impact of mowing, local vegetation, and landscape

641 composition on adult mosquito populations. Urban Ecosystems. 2019;22(5):827-39.

642 51. Wilke AB, Chase C, Vasquez C, Carvajal A, Medina J, Petrie WD, et al. Urbanization

643 creates diverse aquatic habitats for immature mosquitoes in urban areas. Scientific reports.

$644 \quad 2019 ; 9(1): 1-11$.

645 52. Stanton M, Rejmanek M, Galen C. Changes in vegetation and soil fertility along a

646 predictable snowmelt gradient in the Mosquito Range, Colorado, USA. Arctic and Alpine

647 Research. 1994;26(4):364-74.

648 53. Thullen JS, Sartoris JJ, Walton WE. Effects of vegetation management in constructed

649 wetland treatment cells on water quality and mosquito production. Ecological Engineering.

$650 \quad 2002 ; 18(4): 441-57$.

651 54. Gardner AM, Anderson TK, Hamer GL, Johnson DE, Varela KE, Walker ED, et al.

652 Terrestrial vegetation and aquatic chemistry influence larval mosquito abundance in catch basins,

653 Chicago, USA. Parasites \& vectors. 2013;6(1):9.

654 55. Ripoche M, Campagna C, Ludwig A, Ogden NH, Leighton PA. Short-term Forecasting

655 of Daily Abundance of West Nile Virus Vectors Culex pipiens-restuans (Diptera: Culicidae) and

656 Aedes vexans Based on Weather Conditions in Southern Québec (Canada). Journal of medical

657 entomology. 2019;56(3):859-72.

658 56. Wang J, Ogden NH, Zhu H. The impact of weather conditions on Culex pipiens and

659 Culex restuans (Diptera: Culicidae) abundance: a case study in Peel region. Journal of medical

660 entomology. 2011;48(2):468-75. 
661 57. Lebl K, Brugger K, Rubel F. Predicting Culex pipiens/restuans population dynamics by

662 interval lagged weather data. Parasites \& vectors. 2013;6(1):129.

663 58. Diuk-Wasser MA, Brown HE, Andreadis TG, Fish D. Modeling the spatial distribution of 664 mosquito vectors for West Nile virus in Connecticut, USA. Vector-Borne \& Zoonotic Diseases. $6652006 ; 6(3): 283-95$.

666 59. Chen CC, Jenkins E, Epp T, Waldner C, Curry PS, Soos C. Climate change and West 667 Nile virus in a highly endemic region of North America. Int J Environ Res Public Health. 668 2013;10(7):3052-71. doi: 10.3390/ijerph10073052. PubMed PMID: 23880729; PubMed Central 669 PMCID: PMC3734476.

670 60. Bartlow AW, Manore C, Xu C, Kaufeld KA, Del Valle S, Ziemann A, et al. Forecasting 671 Zoonotic Infectious Disease Response to Climate Change: Mosquito Vectors and a Changing 672 Environment. Veterinary sciences. 2019;6(2):40.

673 61. Giordano BV, Kaur S, Hunter FF. West Nile virus in Ontario, Canada: A twelve-year 674 analysis of human case prevalence, mosquito surveillance, and climate data. PLoS One. $675 \quad 2017 ; 12(8): \mathrm{e} 0183568$.

676 62. Trawinski P, Mackay D. Meteorologically conditioned time-series predictions of West 677 Nile virus vector mosquitoes. Vector-Borne and Zoonotic Diseases. 2008;8(4):505-22.

678 63. Trawinski PR, Mackay DS. Identification of environmental covariates of West Nile virus 679 vector mosquito population abundance. Vector-Borne and Zoonotic Diseases. 2010;10(5):51568026.

681 64. Ferraguti M, Martinez-de La Puente J, Figuerola J. Ecological Effects on the Dynamics 682 of West Nile Virus and Avian Plasmodium: The Importance of Mosquito Communities and 
683 Landscape. Viruses-Basel. 2021;13(7). doi: 10.3390/v13071208. PubMed PMID:

684

685

686

687

688

689

690

691

692

693

694

695

696

697

698

699

700

701

702

$703 \quad 71$

704

705

WOS:000676895200001.

65. Reisen WK. Landscape epidemiology of vector-borne diseases. Annual review of entomology. 2010;55:461-83.

66. Madzokere ET, Hallgren W, Sahin O, Webster JA, Webb CE, Mackey B, et al. Integrating statistical and mechanistic approaches with biotic and environmental variables improves model predictions of the impact of climate and land-use changes on future mosquitovector abundance, diversity and distributions in Australia. Parasites \& Vectors. 2020;13(1):1-13. 67. Franklinos LH, Jones KE, Redding DW, Abubakar I. The effect of global change on mosquito-borne disease. The Lancet Infectious Diseases. 2019;19(9):e302-e12.

68. Chuang T-W, Hildreth MB, Vanroekel DL, Wimberly MC. Weather and land cover influences on mosquito populations in Sioux Falls, South Dakota. Journal of medical entomology. 2011;48(3):669-79.

69. Hunt SK, Galatowitsch ML, McIntosh AR. Interactive effects of land use, temperature, and predators determine native and invasive mosquito distributions. Freshwater Biology. 2017;62(9):1564-77.

70. Kache PA, Eastwood G, Collins-Palmer K, Katz M, Falco RC, Bajwa WI, et al. Environmental Determinants of Aedes albopictus Abundance at a Northern Limit of Its Range in the United States. The American Journal of Tropical Medicine and Hygiene. 2020;102(2):43647.

71. McClure KM, Lawrence C, Kilpatrick AM. Land use and larval habitat increase Aedes albopictus (Diptera: Culicidae) and Culex quinquefasciatus (Diptera: Culicidae) abundance in lowland Hawaii. Journal of medical entomology. 2018;55(6):1509-16. 
706 72. Becker N, Petric D, Zgomba M, Boase C, Dahl C, Lane J, et al. Mosquitoes and their

707 control Kluwer Academic. Plenum Publishers, New York; 2003.

708 73. Butt S, Ramprasad P, Fenech A. Changes in the landscape of southern Ontario Canada

709 since 1750: impacts of European colonization. Integrated Mapping Assessment. 2005:83-92.

710 74. Baldwin DJ, Desloges JR, Band LE. Physical geography of Ontario. Ecology of a

711 managed terrestrial landscape: patterns and processes of forest landscapes in Ontario. 2000:12-

71229.

713 75. Thornton P, Thornton M, Mayer B, Wei Y, Devarakonda R, Vose R, et al. Daymet: Daily

714 Surface Weather Data on a 1-km Grid for North America, Version 3. ORNL DAAC, USA. 2017.

715 76. Roiz D, Ruiz S, Soriguer R, Figuerola J. Climatic effects on mosquito abundance in

716 Mediterranean wetlands. Parasites \& vectors. 2014;7(1):333.

717 77. Illinois Department of Public Health. Prevention and control - Mosquitoes and disease

7182017 [updated March 29, 2017]. Available from:

719 https://www.cdc.gov/dengue/resources/factsheets/mosquitolifecyclefinal.pdf.

720 78. Lowe AM, Forest-Bérard K, Trudel R, Lo E, Gamache P, Tandonnet M, et al.

721 Mosquitoes Know No Borders: Surveillance of Potential Introduction of Aedes Species in

722 Southern Québec, Canada. Pathogens. 2021;10(8). Epub 2021/08/29. doi:

723 10.3390/pathogens10080998. PubMed PMID: 34451462; PubMed Central PMCID:

724 PMCPMC8400959.

725 79. Verdonschot PF, Besse-Lototskaya AA. Flight distance of mosquitoes (Culicidae): a

726 metadata analysis to support the management of barrier zones around rewetted and newly

727 constructed wetlands. Limnologica. 2014;45:69-79. 
80. Ovaskainen O, Tikhonov G, Norberg A, Guillaume Blanchet F, Duan L, Dunson D, et al.

729

730

731

732

733

734

735

736

737

738

739

740

741

742

743

744

745

746

747

748

749

750

How to make more out of community data? A conceptual framework and its implementation as models and software. Ecology Letters. 2017;20(5):561-76.

81. Dray S, Legendre P, Peres-Neto PR. Spatial modelling: a comprehensive framework for principal coordinate analysis of neighbour matrices (PCNM). Ecological modelling. 2006;196(34):483-93.

82. Geweke J. Evaluating the accuracy of sampling-based approaches to the calculation of posterior moments: Federal Reserve Bank of Minneapolis, Research Department Minneapolis, $\mathrm{MN} ; 1991$.

83. Efron B. Regression and ANOVA with zero-one data: Measures of residual variation. Journal of the American Statistical Association. 1978;73(361):113-21.

84. Blanchet F, Tikhonov G, Norberg A. HMSC: Hierarchical modelling of species community. R package version 2.0-10. 2017.

85. Team RC. R: A language and environment for statistical computing. Vienna, Austria; 2020.

86. CDC. Mosquito life cycle 2021 [October 13, 2021]. Available from:

https://www.cdc.gov/dengue/resources/factsheets/mosquitolifecyclefinal.pdf.

87. Balestrino F, Benedict M, Gilles J. A new larval tray and rack system for improved mosquito mass rearing. Journal of Medical Entomology. 2012;49(3):595-605.

88. Morris C. Phenology of trophic and gonobiologic states in Culiseta morsitans and Culiseta melanura (Diptera: Culicidae). Journal of medical entomology. 1984;21(1):38-51.

89. Kaufman MG, Fonseca DM. Invasion biology of Aedes japonicus japonicus (Diptera: Culicidae). Annual review of entomology. 2014;59:31-49. 
751 90. Wood DMD, P.T.; R.A. Ellis. . The insects and arachnids of Canada, part 6, the

752 mosquitoes of Canada (Diptera: Culicidae. Biosystematics Research Institute, Ottawa,

753 Ontario1979.

754 91. Darsie R, Hutchinson M. The mosquitoes of Pennsylvania: Identification of adult females

755 and fourth instar larvae, geographical distribution, biology and public health importance.

756 Technical Bulletin. 2009;1.

757 92. Brown H, Diuk-Wasser M, Andreadis T, Fish D. Remotely-sensed vegetation indices

758 identify mosquito clusters of West Nile virus vectors in an urban landscape in the northeastern

759 United States. Vector-Borne and Zoonotic Diseases. 2008;8(2):197-206.

760 93. Crans WJ. A classification system for mosquito life cycles: life cycle types for

761 mosquitoes of the northeastern United States. Journal of Vector Ecology. 2004;29:1-10.

762 94. Winteringham FPW. Environment and chemicals in agriculture. 1985.

763 95. Plimmer J. Chemicals for agriculture. IAEA Bulletin. 1984;26(2):13-6.

766 S1 File.

767 (PDF) 


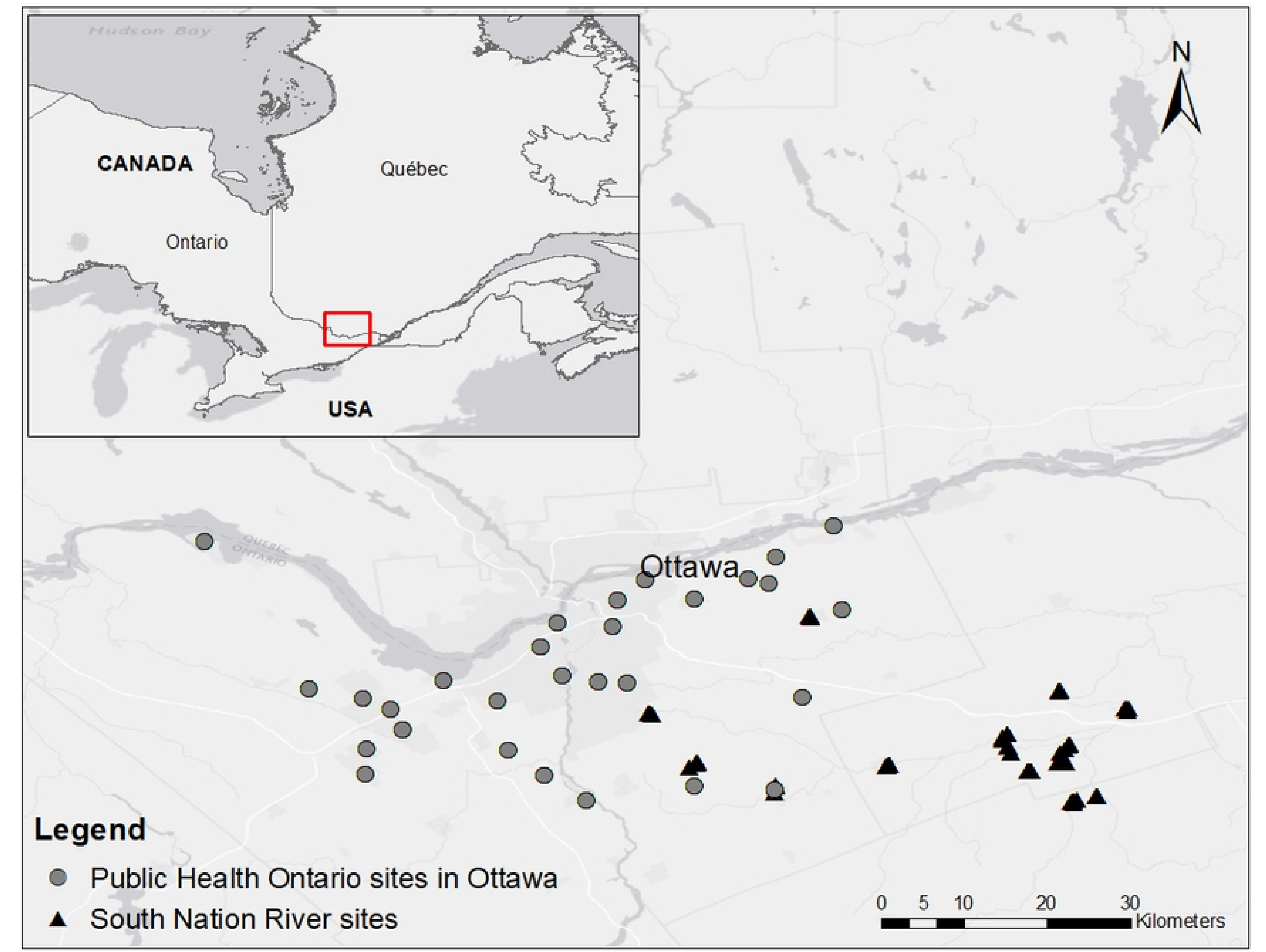

Fig 1 


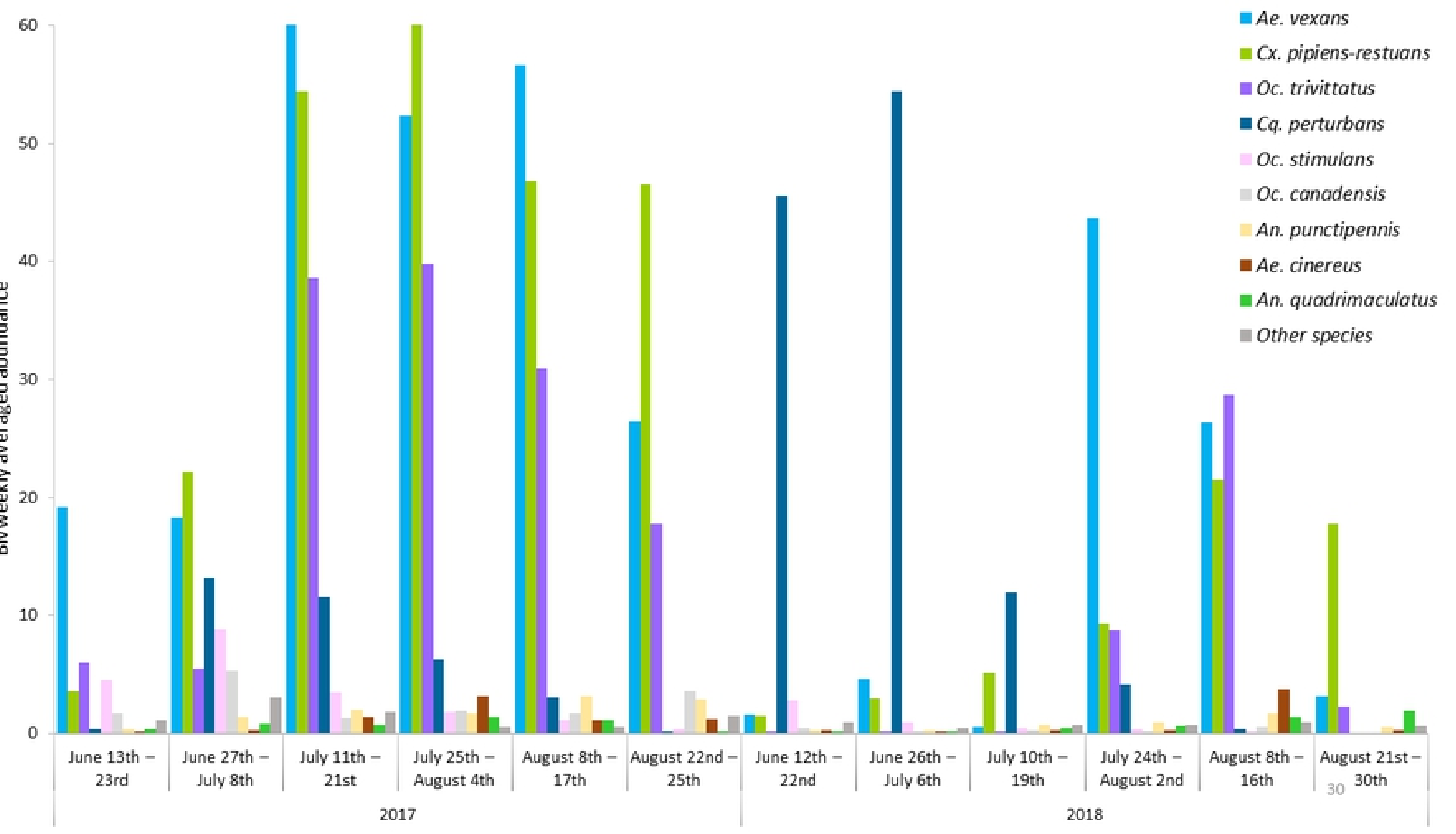

Fig 2 


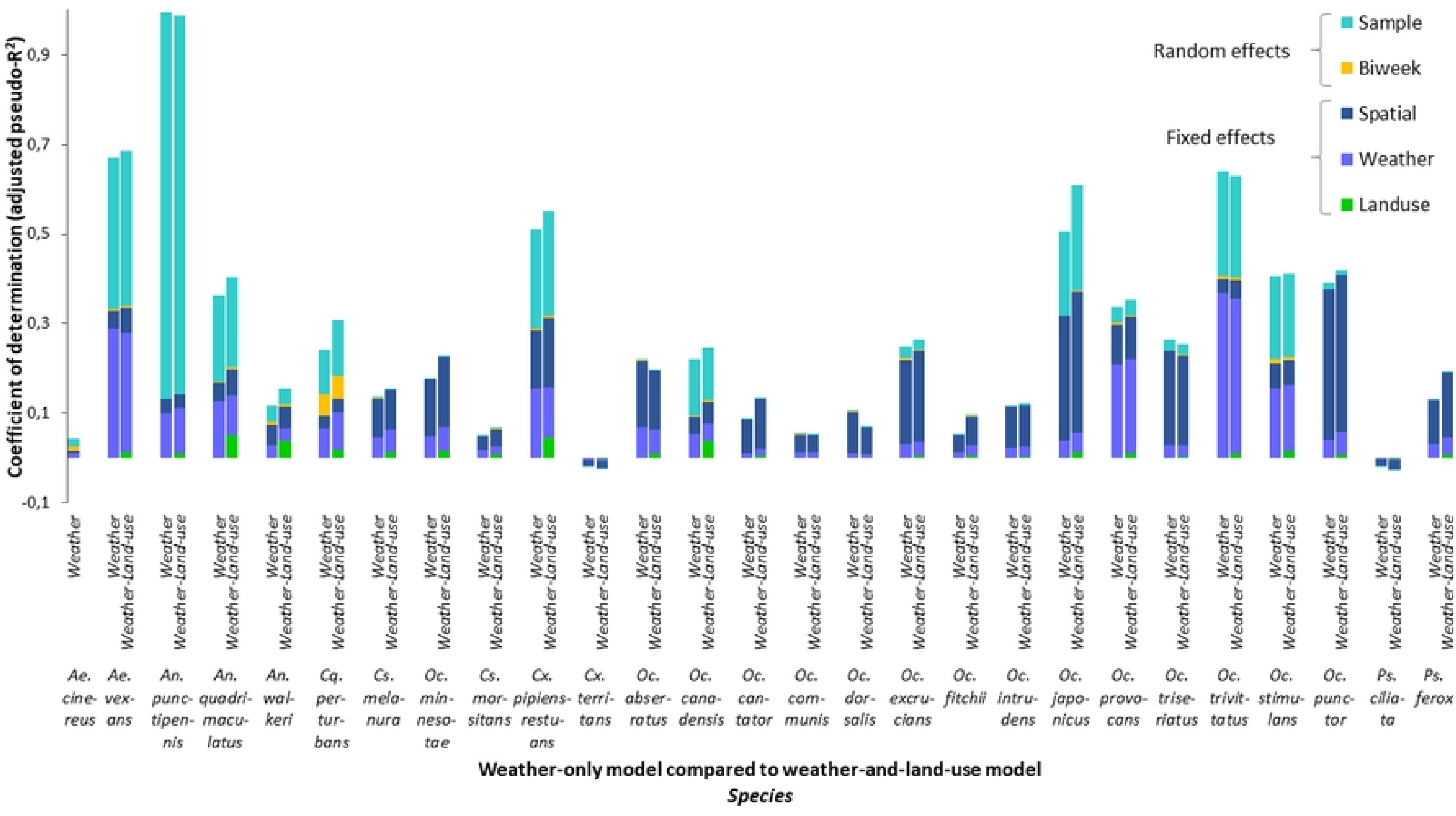

Fig 3 


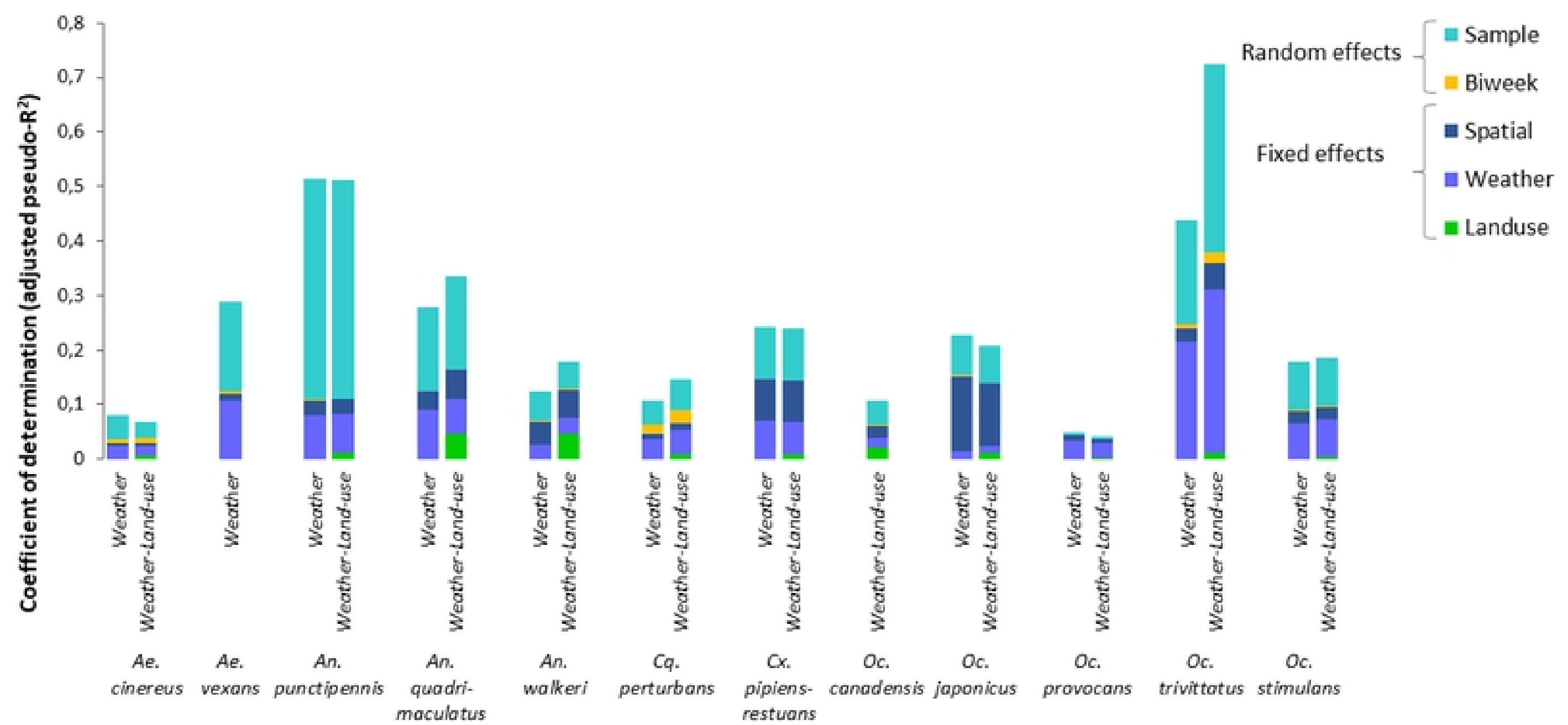

Weather-only model compared to weather-and-land-use model Species

Fig 4 